\title{
A Reduced Number of Metabotropic Glutamate Subtype 5 Receptors Are Associated with Constitutive Homer Proteins in a Mouse Model of Fragile X Syndrome
}

\author{
Raffaella Giuffrida, ${ }^{1}$ Sebastiano Musumeci, ${ }^{3}$ Simona D'Antoni, ${ }^{1,5}$ Carmela Maria Bonaccorso, ${ }^{2,3}$ \\ Anna Maria Giuffrida-Stella, ${ }^{1}$ Ben A. Oostra, ${ }^{4}$ and Maria Vincenza Catania ${ }^{3,5}$ \\ ${ }^{1}$ Department of Chemical Sciences, Section of Biochemistry and Molecular Biology and ${ }^{2}$ Department of Physiological Sciences, University of Catania, 95125 \\ Catania, Italy, ${ }^{3}$ Department of Neurology, Oasi Maria Santissima Institute for Research on Mental Retardation and Brain Aging (Istituto di Ricovero e Cura \\ a Carattere Scientifico), 94018 Troina (EN), Italy, ${ }^{4}$ Department of Clinical Genetics, Erasmus Medical Center, 3000 DR Rotterdam, The Netherlands, and \\ ${ }^{5}$ Institute of Neurological Sciences, Section of Catania, Consiglio Nazionale delle Ricerche, 95123 Catania, Italy
}

Fragile $\mathrm{X}$ (FRAX) syndrome is a common inherited form of mental retardation resulting from the lack of fragile $\mathrm{X}$ mental retardation protein (FMRP) expression. The consequences of FMRP absence in the mechanism underlying mental retardation are unknown. Here, we tested the hypothesis that glutamate receptor (GluR) expression might be altered in FRAX syndrome. Initial in situ hybridization and Western blotting experiments did not reveal differences in mRNA levels and protein expression of AMPA and NMDA subunits and metabotropic glutamate subtype 5 (mGlu5) receptors between control and Fmr1 knock-out (KO) mice during postnatal development. However, a detergent treatment (1\% Triton X-100) revealed a selective reduction of mGlu5 receptor expression in the detergent-insoluble fraction of synaptic plasma membranes (SPMs) from K0 mice, with no difference in the expression of NR2A, GluR1, GluR2/3, GluR4, and Homer proteins. mGlu5 receptor expression was also lower in Homer immunoprecipitates from Fmr1 K0 SPMs. Homer, but not NR2A, mGlu5, and GluR1, was found to be less tyrosine phosphorylated in Fmr1 K0 than control mice. Our data indicate that, in FRAX syndrome, a reduced number of mGlu5 receptors are tightly linked to the constituents of postsynaptic density and, in particular, to the constitutive forms of Homer proteins, with possible consequent alterations in synaptic plasticity.

Key words: mental retardation; synaptosomes; synaptic plasticity; glutamate receptors; Homer; tyrosine phosphorylation

\section{Introduction}

Fragile X (FRAX) syndrome is a common hereditary neurodevelopmental disorder associated with mental retardation, which is caused by the transcriptional silencing of the Fmrl gene (Jin and Warren, 2003). Fragile X mental retardation protein (FMRP) is an RNA-binding protein that can function as a negative regulator of protein synthesis (Laggerbauer et al., 2001; Li et al., 2001; Sung et al., 2003; Zalfa et al., 2003). Despite the progress in elucidating the function of FMRP (Brown et al., 2001; Darnell et al., 2001), the consequences of its absence in the mechanisms of mental retardation are unknown.

The lack of FMRP might interfere with important mechanisms underlying synaptic plasticity. Brains of affected humans

\footnotetext{
Received Aug. 18, 2003; revised Aug. 11, 2005; accepted Aug. 14, 2005.

This work was supported by a grant from the Health Ministry of Italy, Consiglio Nazionale delle Ricerche, and Ministero dell'Istruzione, dell'Università, e della Ricerca-Fondo per gli Investimenti della Ricerca di Base Grant RBAU01BA3A-002. We thank A. Costa (Department of Biochemistry, University of Catania, Catania, Italy), G. Barrancotto, and A. Gloria (Istituto di Ricovero e Cura a Carattere Scientifico-0asi Maria Santissima, Troina, Italy) for technical support. We gratefully acknowledge the support of Società Industria Farmaceutica Italiana and thank Dr. Carla Amico for critically reading this manuscript.

Correspondence should be addressed to Dr. Maria Vincenza Catania, Institute of Neurological Sciences, Section of Catania, Consiglio Nazionale delle Ricerche, viale Regina Margherita 6, 95123 Catania, Italy. E-mail: m.catania@isn.cnr.it.

DOI:10.1523/JNEUROSCI.0932-05.2005

Copyright $\odot 2005$ Society for Neuroscience $\quad 0270-6474 / 05 / 258908-09 \$ 15.00 / 0$
}

and Fmr1 knock-out (KO) mice show an increased density of long and tortuous dendritic spines, suggesting a delay in spine maturation (Hinton et al., 1991; Comery et al., 1997; Nimchinsky et al., 2001). FMRP is present in dendrites and spines, in which it is locally synthesized by an activity-dependent mechanism triggered by the activation of group I metabotropic glutamate receptors (mGluRs) (Weiler et al., 1997; Antar et al., 2004). The presence of FMRP is also necessary for group I mGluR-activated protein translation at synapses (Weiler et al., 2004; Aschrafi et al., 2005). Interestingly, group I mGluR-mediated long-term depression (LTD) is enhanced in Fmrl KO mice, whereas NMDAdependent LTD is not (Huber et al., 2002; Bear et al., 2004). In addition, whereas normal synaptic transmission does not differ between wild-type (wt) and Fmr1 KO mice, cortical long-term potentiation (LTP) has been found to be reduced in Fmrl KO mice (Li et al., 2002).

Synaptic plasticity is likely to be mediated by mechanisms that regulate the trafficking and recycling of glutamate receptors at the synapses (Scannevin and Huganir, 2000; Carrol et al., 2001). Different postsynaptic density (PSD) scaffolding proteins interact with glutamate receptors, which are, consequently, differentially anchored to the plasma membrane. Homer is a family of PSD scaffolding proteins that cross-link group I mGluRs (mGlul and mGlu5) to inositol triphosphate receptors and to other PSD pro- 
teins (Tu et al., 1998, 1999). Homer proteins are classified as short (Homer1a) and long (Homer1b/c, Homer2, and Homer3) isoforms. Homerla lacks the coiled-coil motif at the C-terminal region, which mediates self-multimerization between long forms of Homer (Xiao et al., 1998).

Here, we analyzed the expression levels of AMPA and NMDA receptor subunits, mGlu5 receptors, and Homer short (Homerla) and long (Homer) isoforms in Fmrl KO and control mice. To investigate whether glutamate receptors might be differently linked to the PSD structures in wt and Fmrl KO mice, we performed Western blotting experiments on synaptic plasma membrane (SPM) proteins treated or not with Triton X-100, a non-ionic detergent that discriminates between synaptic proteins differently associated to PSD. We found that mGlu5 receptors were significantly less expressed in the Triton X-100-insoluble fraction of SPMs of Fmr1 KO than wt mice, whereas all of the other proteins were similarly expressed in both treated and untreated SPMs from Fmr $1 \mathrm{KO}$ and wt animals. Immunoprecipitation (IP) experiments revealed both a reduced association of mGlu5 receptors with Homer and a decreased tyrosine phosphorylation of Homer in Fmr1 KO compared with wt mice.

\section{Materials and Methods}

Experimental animals

Fmr1 KO mice of the FVB strain and their wt littermates were used as controls. Genotypes were determined by PCR analysis of DNA extracted from tails. The primers used were the same as those indicated in the original paper describing these animals (Dutch-Belgian Fragile X Consortium, 1994). Day of birth was considered postnatal day 0 (P0). No gross anatomical differences were found between Fmrl KO and wt brains. Weight of Fmr1 KO and wt brains was identical at different postnatal ages (data not shown).

\section{Oligonucleotide probes}

The following antisense oligonucleotide probes ( $\sim 45$-mers $)$ were designed to detect the in situ hybridization signal for the different AMPA subunits and the mGlu5 receptor subtype: GluR1, gtcactggttgtctgatctcgtccttcttcaaactcttcactgtg, complementary to nucleotide residues 1959-2003 of the GluR1 subunit cDNA from mouse (Sakimura et al., 1990); GluR2, ttcactactttgtgtttctcttccatcttcaaattcctcagtgtg, complementary to nucleotide residues 1919-1963 of the GluR2 subunit cDNA from mouse (Sakimura et al., 1990); GluR2bis, gtcgatatggggtgtcagtctgaactccgaagtggaaaactgaac, complementary to nucleotide residues 347-391 of the GluR2 subunit cDNA from mouse (Sakimura et al., 1990); GluR3, agggctttgtgggtcacgaggttcttcattgttgtcttccaagtg, complementary to nucleotide residues 1780-1824 of the GluR3 subunit cDNA from mouse (Sommer et al., 1991); GluR3bis, ggcttctcagtggtgttctggttggtgttgtataactgcacag, complementary to nucleotide residues 197-239 of the GluR3 subunit cDNA from mouse (Sommer et al., 1991); GluR4, tggtcactgggtccttcttttccatcctcaggctcttctgtgtg, complementary to nucleotide residues 1933-1976 of the GluR4 subunit cDNA from mouse (Sommer et al., 1991); GluR4bis, ttgggtgcttttaggttatgacagctttccctcaacaatccatcc, complementary to nucleotide residues $19-63$ of the GluR4 subunit cDNA from mouse (Sommer et al., 1991); mGlu5, attagcactattgatctcatgtctccaccgtgtgtgccctt; and mGlu5bis, atgaattagcactattgatctcatgtctccaccgtgtgtgccctt, complementary to the expressed sequence tagged mouse sequence mu74h05.yl similar to mGlu5 receptor, which was found by using the rat mGlu5 as query sequence in the basic local alignment search tool BLAST database search program.

The probes were $3^{\prime}$ end-labeled by using terminal deoxynucleotidyl transferase (Boehringer Mannheim, Mannheim, Germany) and a 30:1 molar ratio of $\left[\alpha-{ }^{35} \mathrm{~S}\right] \mathrm{dATP}(1300 \mathrm{Ci} / \mathrm{mmol}$, NEG-034H; DuPont-NEN, Boston, MA)/oligonucleotide. Unincorporated nucleotides were removed by Bio-Spin 6 columns (Bio-Rad, Hercules, CA).

\section{In situ hybridization}

Brains from wt and Fmrl KO mice at different postnatal days (P3, P5, P7, P10, P14, P21, P30, and adult) were removed from the skull and frozen on dry ice. Sagittal sections (15 $\mu \mathrm{m})$ were cut at the cryostat, mounted onto poly-L-lysine-coated glass slides, air dried, and stored at $-80^{\circ} \mathrm{C}$. On the day of the experiment, the sections were thawed, allowed to air dry, and processed for the hybridization as described by Monyer et al. (1991). Briefly, sections were fixed for $5 \mathrm{~min}$ in $4 \%$ paraformaldehyde, washed in PBS, pH 7.4, and dehydrated by consecutive dipping in 70 and $95 \%$ ethanol. Sections were then incubated overnight at $42^{\circ} \mathrm{C}$ with hybridization buffer [ $50 \%$ formamide (v/v), $0.06 \mathrm{~m}$ sodium citrate ( $4 \times \mathrm{SSC}), 10 \%$ dextrane sulfate $(\mathrm{w} / \mathrm{v}), 25 \mathrm{~mm}$ sodium phosphate, $1 \mathrm{~mm}$ sodium pyrophosphate, $5 \times$ Denhardt's solution (Sigma, St. Louis, MO), $0.2 \mathrm{mg} / \mathrm{ml}$ salmon sperm DNA, and $0.1 \mathrm{mg} / \mathrm{ml}$ poliadenilic acid] containing the labeled probe $(1 \mathrm{pg} / \mu \mathrm{l}, 1000 \mathrm{dpm} / \mu \mathrm{l})$. The day after, sections were washed at a final stringency of $0.1 \times$ SSC at $55^{\circ} \mathrm{C}$ for $30 \mathrm{~min}$ before dehydration and exposure to Kodak XAR-5 film (Eastman Kodak, Rochester, NY). The autoradiographic film was developed after an exposure time of $20-30 \mathrm{~d}$ at $-80^{\circ} \mathrm{C}$.

\section{Total membrane proteins preparation}

Frozen forebrains and cerebella from control and Fmrl KO mice were allowed to thaw on ice, weighed, and homogenized in $10 \%(\mathrm{w} / \mathrm{v})$ buffer containing $20 \mathrm{~mm}$ Tris- $\mathrm{HCl}$, pH 7.4, $20 \mu \mathrm{g} / \mathrm{ml}$ leupeptin, $20 \mu \mathrm{g} / \mathrm{ml}$ aprotinin, $0.1 \mathrm{~mm}$ phenylmethylsulfonyl fluoride (PMSF), $1 \mathrm{~mm}$ EDTA, $5 \mathrm{~mm}$ EGTA, and $10 \%$ sucrose. The homogenate was centrifuged for $10 \mathrm{~min}$ at $1000 \times g\left(4^{\circ} \mathrm{C}\right)$ to separate the nuclear pellet. The supernatant was then centrifuged for $30 \mathrm{~min}$ at $114,000 \times g\left(4^{\circ} \mathrm{C}\right)$, and the resulting pellet was washed once with the same buffer lacking sucrose and centrifuged again. The pellet formed by total membrane proteins (TMPs) was resuspended in Tris buffer (40 mm Tris-HCl, pH 6.8, $20 \mu \mathrm{g} / \mathrm{ml}$ leupeptin, $20 \mu \mathrm{g} / \mathrm{ml}$ aprotinin, $0.1 \mathrm{~mm}$ PMSF, $1 \mathrm{~mm}$ EDTA, and $5 \mathrm{~mm}$ EGTA); $5 \mu$ of this suspension was used to determine the protein content by using the bicinchoninic acid method (BCA kit; Pierce, Rockford, IL), and the rest was stored at $-80^{\circ} \mathrm{C}$ until use.

Synaptic plasma membrane preparation and detergent treatment Frozen forebrains and cerebella from control and Fmrl KO mice were allowed to thaw on ice, weighed, and homogenized in $10 \%(\mathrm{w} / \mathrm{v}) 0.32 \mathrm{M}$ sucrose buffer containing $1 \mathrm{~mm}$ EDTA, $10 \mathrm{~mm}$ Tris- $\mathrm{HCl}$, $\mathrm{pH}$ 7.4, and 0.5 mM PMSF. The homogenate was centrifuged for $10 \mathrm{~min}$ at $1000 \times \mathrm{g}\left(4^{\circ} \mathrm{C}\right)$ to separate the nuclear pellet. The supernatant was then centrifuged for $30 \mathrm{~min}$ at $10,000 \times g\left(4^{\circ} \mathrm{C}\right)$, and the resulting pellet was resuspended with the $0.32 \mathrm{M}$ sucrose buffer, layered on top of discontinuous sucrose gradient $(0.8,1.0$, and $1.2 \mathrm{M})$, and centrifuged for $2 \mathrm{~h}$ at $75,000 \times g\left(4^{\circ} \mathrm{C}\right)$. The synaptic plasma membrane fractions were stratified at the interface between $0.8 / 1$ and $1 / 1.2 \mathrm{M}$ sucrose. The recovered synaptosomes were diluted with $\mathrm{H}_{2} \mathrm{O}$ to obtain a sucrose final concentration of $0.32 \mathrm{M}$ and centrifuged for $1 \mathrm{~h}$ at $53,000 \times g\left(4^{\circ} \mathrm{C}\right)$. The pellets were resuspended in $40 \mathrm{~mm}$ Tris- $\mathrm{HCl}$, pH 6.8, containing $0.5 \mathrm{~mm}$ PMSF; $5 \mu$ l of this suspension was used to determine the protein content by using the $\mathrm{BCA}$ method, and the rest was stored at $-80^{\circ} \mathrm{C}$ until use.

Twenty or $30 \mu \mathrm{g}$ of SPM fractions were treated with 300 or $450 \mu \mathrm{l}$ of Triton X-100 extraction buffer ( $40 \mathrm{~mm}$ Tris- $\mathrm{HCl}, \mathrm{pH} 6.8,150 \mathrm{~mm} \mathrm{NaCl}$, $1 \mathrm{~mm}$ EDTA, $2.5 \mathrm{~mm}$ sodium pyrophosphate, $1 \mu \mathrm{g} / \mathrm{ml}$ leupeptin, $0.1 \mathrm{~mm}$ PMSF, $2 \mu \mathrm{g} / \mathrm{ml}$ aprotinin, and $1 \%$ Triton X-100) in ice for $15 \mathrm{~min}$, shortly vortexing every $5 \mathrm{~min}$. The resulting mixture was centrifuged for $15 \mathrm{~min}$ at $16,000 \times g\left(4^{\circ} \mathrm{C}\right)$, and the pellet was washed with extraction buffer containing $0.5 \%$ Triton X-100, centrifuged again, and resuspended in $10 \mu \mathrm{l}$ of $40 \mathrm{~mm}$ Tris-HCl, $\mathrm{pH}$ 6.8. In a few experiments, 0.2 or $1 \%$ Sarkosyl was used instead of Triton X-100. The detergent-insoluble pellet and an equal amount ( 20 or $30 \mu \mathrm{g}$ ) of detergent-untreated SPMs were boiled in $2 \times$ denaturing sample buffer containing SDS for $3 \mathrm{~min}$ and processed for Western blotting analysis. Only for mGlu5 receptor untreated and treated proteins was the denaturation step performed at $37^{\circ} \mathrm{C}$.

\section{Immunoprecipitation}

Chemical cross-linking. Protein A-Sepharose and protein G-Sepharose beads (Sigma) were gently mixed over night in $0.1 \mathrm{~m}$ borate buffer, $\mathrm{pH}$ 8.0 , at $4^{\circ} \mathrm{C}$ with $10 \mu \mathrm{g}$ of rabbit anti-Homer (SC-15321; Santa Cruz Biotechnology, Santa Cruz, CA) and $10 \mu \mathrm{g}$ of goat anti-Homerla (SC8922; Santa Cruz Biotechnology) antibodies, respectively. After coupling, beads were washed in borate buffer, the cross-linking reagent, 20 
mu dimethylpimelimidate in $200 \mathrm{~mm}$ sodium borate, $\mathrm{pH}$ 9.0, was added, and the mixture was gently shaken for $30 \mathrm{~min}$ at room temperature. After washing, the reaction was blocked with $0.2 \mathrm{M}$ ethanolamine, $\mathrm{pH}$ 8.0. Homer 1a-coupled G-Sepharose beads were further treated in $0.1 \mathrm{M}$ glycine at $\mathrm{pH} 3.0$ for $30 \mathrm{~min}$ to eliminate the IgG light chains $(26 \mathrm{kDa})$ of the primary antibody not covalently linked to the beads (Harlow and Lane, 1988), which might interfere with the detection of Homerla band (30 $\mathrm{kDa}$ ) Western blotting experiments.

Immunoprecipitation. For immunoprecipitation, $30 \mu \mathrm{g}$ of SPMs were added to the Sepharose-coupled Homer and Homerla antibodies in a final volume of $600 \mu \mathrm{l}$ of IP buffer (50 mM HEPES, pH 7.5, $150 \mathrm{~mm} \mathrm{NaCl}$, $10 \%$ glycerol, $1.5 \mathrm{~mm} \mathrm{MgCl}$, 1 mм EDTA, $10 \mathrm{~mm}$ Na pyrophosphate, 0.1 mм $\mathrm{NaVO}_{3}, 1$ mм PMSF, 1 mм NaF, 2 mм DTT, $10 \mu \mathrm{g} / \mathrm{ml}$ aprotinin, 10 $\mu \mathrm{g} / \mathrm{ml}$ leupeptin, and $1 \%$ Triton $\mathrm{X}-100$ ), and the mixture was kept in constant rotation at $4^{\circ} \mathrm{C}$ for $2 \mathrm{~h}$. Then, the Homer-coupled beads were extensively washed with the buffer to remove unlinked proteins. The pellet was boiled in $2 \times$ denaturing sample buffer containing SDS for 5 min to uncouple the immunoprecipitated proteins from the beads, and then the supernatant was loaded onto SDS-polyacrylamide gels and processed for Western blotting analysis. As negative controls, protein A-Sepharose and protein G-Sepharose beads coupled with the unrelated anti-CD45 rabbit (Santa Cruz Biotechnology) and anti-calretinin goat (Swant, Bellinzona, Switzerland) primary antibodies were used and failed to immunoprecipitate Homer/mGlu5 and Homerla/mGlu5, respectively (data not shown).

Phosphotyrosine immunoprecipitation. Phosphotyrosine (PY) beads [Santa Cruz Biotechnology or Upstate Biotechnology (Lake Placid, NY)] were washed three times with IP buffer and mixed to $30 \mu \mathrm{g}$ of SPM proteins overnight at $4^{\circ} \mathrm{C}$. The protein-coupled beads were washed three times with IP buffer, the pellet was boiled for $5 \mathrm{~min}$ in $2 \times$ denaturing sample buffer containing SDS, and the supernatant was loaded onto 7.5\% SDS-polyacrylamide gels and processed for Western blotting analysis. A control experiment performed using IP buffer lacking phosphatase inhibitors $\left(\mathrm{NaF}, \mathrm{Na}\right.$ pyrophosphate, and $\mathrm{NaVO}_{3}$ ) in all steps of the procedure showed a strong reduction of PY-immunoprecipitated proteins (see Fig. 6).

\section{Western blotting}

After the denaturating step, proteins were loaded onto $7.5 \%$ SDSpolyacrylamide gels. Only for Homerla-immunoprecipitated proteins were $12 \%$ SDS-polyacrylamide gels used. Gels were electroblotted to nitrocellulose membranes (Hybond C-extra; Amersham Biosciences, Buckinghamshire, UK) by using a transblot SD apparatus (Bio-Rad, Hercules, CA). Filters were blocked for $1 \mathrm{~h}$ in $5 \%$ nonfat dried milk in TTBS (Tris $100 \mathrm{~mm}, 0.9 \% \mathrm{NaCl}$, and $1 \%$ Tween 20 ). Blots were then incubated for $2 \mathrm{~h}$ with the following primary rabbit polyclonal antibodies: antiGluR1 (1:1000), anti-GluR2 (1:200), anti-GluR2/3 (1:200), anti-GluR4 (1:500), anti-NR1 (1:200), anti-NR2A (1:1000), and anti-NR2B (1:200) (Chemicon, Temecula, CA); anti-mGlu5 (1:400; Upstate Biotechnology); and anti-Homer (1:1000; Santa Cruz Biotechnology); and with the primary goat polyclonal anti-Homer1a (1:1000; Santa Cruz Biotechnology). The anti-Homer antibody is raised against an epitope corresponding to amino acids 13-354 of Homerlb of human origin, and it reacts with all Homer long isoforms and always recognized a single band of $\sim 47$ $\mathrm{kDa}$ (see Fig. 3B). Filters were rinsed in TTBS buffer and incubated for $1 \mathrm{~h}$ with the anti-rabbit or anti-goat secondary antibodies conjugated with horseradish peroxidase. After washing, an enhanced chemiluminescent detection method (ECL plus; Amersham Biosciences) was performed to develop filter signals.

\section{Data analysis}

Signals obtained from films of in situ hybridization and Western blotting experiments were quantified by computer-assisted densitometry, using the MCID system (Imaging Research, St. Catharines, Ontario, Canada). Images were visualized under the same light condition on a video monitor connected to the illuminator through a video camera. The integrated optical density (OD) was obtained by the software-operated conversion of absolute gray values in arbitrary OD units. This computation was done after obtaining a linear calibration curve generated by the system, attrib- uting the arbitrary value of 0 to the lightest gray value and 100 to the highest value. These values were averaged from several readings in different experiments.

\section{Results}

Developmental profile of AMPA subunit and mGlu5 receptor mRNA expression is comparable in Fmr1 $\mathrm{KO}$ and control mice

The mRNA expression pattern of AMPA receptor subunits and mGlu5 receptors during development was examined in the cortex, striatum, hippocampus, and cerebellum and found to be similar to that described previously (Monyer et al., 1991; Catania et al., 1994). Briefly, mRNAs for all tested receptors were already present at P3. The highest levels during development were found at P14 in the hippocampus for GluR1, GluR2, GluR3, and mGlu5 and in the cerebellum for GluR4 (Table 1). Depending on the brain region, signal intensity decreased or increased with age. We observed a decrease in GluR1, GluR2, GluR4, and mGlu5 receptor mRNA signal intensity in the cortex and striatum between P5-P7 and P21. GluR3 mRNA expression increased in the cortex up to P14 and then slightly decreased to adult levels, whereas in the striatum, a moderate decrease was observed from P3-P5 to the adult. In the hippocampus, GluR1, GluR2, GluR3, and mGlu5 receptor mRNA expression had a comparable developmental pattern with a moderate increase up to P14, followed by a smooth reduction to the adult levels. In the cerebellum, specific developmental patterns were observed for each receptor. GluR1 moderately increased up to P14 and then decreased. GluR2 increased between P3 and P5, remained stable up to P14, and then slightly decreased. GluR3 decreased between P5 and adult. GluR4 was low at P3 and reached the adult levels by P14. mGlu5 was expressed between P5 and P14 with a peak at P7 and then drastically dropped at P21. Semiquantitative analysis of film autoradiographic signal did not reveal any statistically significant difference between Fmr1 KO and control mice at any developmental stage in any analyzed brain region (Fig. 1, Table 1).

\section{mGlu5 receptors are reduced in the Triton $\mathrm{X}$-100-insoluble fraction of SPMs of Fmr1 KO mice}

Initial Western blotting experiments were performed on TMPs. These experiments did not show any difference in the expression of GluR1, GluR2/3, GluR4, NR1, NR2A, NR2B, mGlu5, and Homer long (Homer) and short (Homerla) isoforms in the forebrain and GluR4 in the cerebellum between Fmr1 KO and control animals at different postnatal days (P5, P10, P14, P21, P30, and 11 months) (Figs. 2, 3B).

To investigate whether glutamate receptors might be differently linked to the cytoskeleton structures of PSD in wt and Fmr1 $\mathrm{KO}$ mice, we decided to perform Western blotting experiments on SPMs that were either treated or not with $1 \%$ Triton X-100. All of the experiments were performed at P21. We chose this age because the highest degree of susceptibility to audiogenic seizure has been found at P21 (Musumeci et al., 2000), and mGlu5dependent LTD has been found to be increased in Fmr1 KO animals tested at P21-P30 (Huber et al., 2002). We found no difference in the expression of the proteins examined between Fmr1 KO and control mice in the untreated SPMs as reported above for TMPs (Fig. $3 A, B$ ). Triton X-100 treatment solubilized $\sim 60 \%$ of synaptic proteins in both wt and Fmr1 KO mice, as measured by the signal intensity of filters colored with red ponceau (wt, $59 \pm 2.3 \%$; KO, $63 \pm 2.8 \%$ in the forebrain; $n=20$; data not shown). The degree of solubility to $1 \%$ cold Triton X-100 was different in both wt and Fmrl KO mice for AMPA subunits, 
Table 1. Developmental profile of AMPA receptor subunit and mGlu5 receptor subtype mRNA expression was comparable in $F m r 1 \mathrm{~K} 0$ and control mice

\begin{tabular}{|c|c|c|c|c|c|c|c|c|}
\hline \multirow[b]{2}{*}{$P$} & \multicolumn{2}{|l|}{ CTX } & \multicolumn{2}{|l|}{ STR } & \multicolumn{2}{|l|}{ HIPP } & \multicolumn{2}{|l|}{ CB } \\
\hline & wt & Fmr1 K0 & wt & Fmr1 K0 & wt & Fmr1 K0 & wt & Fmr1 K0 \\
\hline \multicolumn{9}{|l|}{ GluR1 } \\
\hline 3 & $17.5 \pm 0.1$ & $14.2 \pm 2.9$ & $34.8 \pm 8.3$ & $36.6 \pm 5.6$ & $65.4 \pm 2.0$ & $64.1 \pm 12.5$ & nd & nd \\
\hline 5 & $19.0 \pm 2.1$ & $17.5 \pm 3.4$ & $28.5 \pm 3.1$ & $25.8 \pm 1.8$ & $72.6 \pm 5.3$ & $64.9 \pm 6.5$ & $31.7 \pm 3.7$ & $31.6 \pm 2.9$ \\
\hline 7 & $15.3 \pm 1.7$ & $16.2 \pm 2.6$ & $23.1 \pm 2.9$ & $21.6 \pm 1.8$ & $78.5 \pm 2.6$ & $75.7 \pm 7.5$ & $43.9 \pm 3.6$ & $37.7 \pm 2.9$ \\
\hline 10 & $11.2 \pm 1.2$ & $13.1 \pm 1.5$ & $19.0 \pm 1.9$ & $18.1 \pm 1.4$ & $83.4 \pm 4.6$ & $87.2 \pm 4.1$ & $36.5 \pm 1.0$ & $32.5 \pm 2.0$ \\
\hline 14 & $11.6 \pm 2.4$ & $11.2 \pm 1.6$ & $19.1 \pm 1.1$ & $20.4 \pm 2.1$ & $91.9 \pm 1.9$ & $93.3 \pm 3.2$ & $46.3 \pm 2.2$ & $40.7 \pm 3.6$ \\
\hline 21 & $9.6 \pm 1.5$ & $10.6 \pm 1.2$ & $15.1 \pm 0.2$ & $16.7 \pm 3.0$ & $87.6 \pm 4.1$ & $82.9 \pm 4.8$ & $34.7 \pm 1.1$ & $36.5 \pm 4.5$ \\
\hline 33 & $10.1 \pm 1.0$ & $11.2 \pm 0.5$ & $11.4 \pm 0.1$ & $12.2 \pm 0.5$ & $79.3 \pm 2.8$ & $78.5 \pm 6.6$ & $27.4 \pm 0.8$ & $25.3 \pm 1.5$ \\
\hline $\mathrm{Ad}$ & $8.8 \pm 1.7$ & $11.3 \pm 4.0$ & $9.5 \pm 2.4$ & $8.3 \pm 5.2$ & $75.6 \pm 7.8$ & $78.2 \pm 7.4$ & $27.5 \pm 1.0$ & $23.8 \pm 2.9$ \\
\hline \multicolumn{9}{|l|}{ GluR2 } \\
\hline 3 & $43.0 \pm 4.3$ & $41.7 \pm 3.9$ & $49.6 \pm 4.0$ & $39.2 \pm 5.1$ & $71.2 \pm 3.1$ & $69.6 \pm 4.8$ & $46.8 \pm 10.8$ & $47.5 \pm 2.5$ \\
\hline 5 & $44.8 \pm 2.4$ & $44.1 \pm 2.1$ & $48.7 \pm 3.5$ & $46.8 \pm 2.4$ & $79.5 \pm 2.9$ & $79.2 \pm 2.9$ & $55.9 \pm 6.7$ & $60.3 \pm 6.7$ \\
\hline 7 & $46.9 \pm 3.0$ & $50.0 \pm 3.1$ & $44.2 \pm 4.4$ & $49.4 \pm 3.2$ & $77.3 \pm 3.1$ & $79.9 \pm 4.7$ & $56.6 \pm 6.8$ & $61.6 \pm 8.5$ \\
\hline 10 & $46.2 \pm 4.0$ & $48.7 \pm 2.4$ & $38.1 \pm 3.9$ & $43.9 \pm 2.9$ & $79.4 \pm 5.2$ & $84.0 \pm 3.4$ & $57.4 \pm 7.5$ & $57.5 \pm 5.5$ \\
\hline 14 & $42.0 \pm 2.8$ & $45.4 \pm 3.1$ & $36.1 \pm 3.7$ & $40.2 \pm 2.3$ & $85.3 \pm 5.9$ & $87.8 \pm 3.4$ & $58.1 \pm 7.5$ & $62.8 \pm 7.1$ \\
\hline 21 & $37.3 \pm 4.0$ & $40.7 \pm 5.4$ & $38.4 \pm 7.0$ & $40.1 \pm 9.2$ & $75.4 \pm 4.3$ & $80.3 \pm 5.9$ & $51.8 \pm 9.5$ & $53.9 \pm 9.6$ \\
\hline 33 & $30.1 \pm 4.0$ & $34.6 \pm 5.8$ & $29.9 \pm 4.0$ & $34.1 \pm 6.3$ & $69.6 \pm 5.7$ & $71.7 \pm 7.1$ & $43.9 \pm 8.4$ & $43.7 \pm 7.4$ \\
\hline $\mathrm{Ad}$ & $32.4 \pm 3.5$ & $31.3 \pm 2.2$ & $32.9 \pm 1.7$ & $36.1 \pm 2.0$ & $72.2 \pm 2.8$ & $69.7 \pm 5.8$ & $46.8 \pm 2.8$ & $46.7 \pm 1.4$ \\
\hline \multicolumn{9}{|l|}{ GluR3 } \\
\hline 3 & $39.1 \pm 7.9$ & $34.5 \pm 9.3$ & $40.0 \pm 10.0$ & $46.6 \pm 8.3$ & $63.8 \pm 2.5$ & $71.6 \pm 5.6$ & nd & $59.8 \pm 10.5$ \\
\hline 5 & $42.0 \pm 5.6$ & $39.5 \pm 12.1$ & $44.7 \pm 9.0$ & $41.9 \pm 6.0$ & $75.0 \pm 8.7$ & $70.3 \pm 5.7$ & $73.9 \pm 6.8$ & $72.3 \pm 3.5$ \\
\hline 7 & $36.0 \pm 3.3$ & $41.0 \pm 2.9$ & $42.5 \pm 3.7$ & $47.2 \pm 4.9$ & $63.8 \pm 3.0$ & $67.6 \pm 3.8$ & $59.8 \pm 6.2$ & $55.5 \pm 6.3$ \\
\hline 10 & $57.4 \pm 9.7$ & $49.7 \pm 8.5$ & $40.9 \pm 5.6$ & $39.1 \pm 5.8$ & $71.4 \pm 8.0$ & $64.8 \pm 5.5$ & $64.8 \pm 6.5$ & $60.5 \pm 6.7$ \\
\hline 14 & $58.8 \pm 4.1$ & $55.9 \pm 11.7$ & $34.4 \pm 5.1$ & $34.4 \pm 5.7$ & $87.6 \pm 4.0$ & $80.7 \pm 6.5$ & $53.1 \pm 7.6$ & $59.2 \pm 7.9$ \\
\hline 21 & $51.8 \pm 3.6$ & $55.4 \pm 2.7$ & $35.9 \pm 5.2$ & $35.5 \pm 4.1$ & $80.0 \pm 5.5$ & $85.7 \pm 8.6$ & $55.5 \pm 8.6$ & $62.4 \pm 6.0$ \\
\hline 33 & $44.7 \pm 6.0$ & $43.6 \pm 4.6$ & $32.6 \pm 6.9$ & $32.5 \pm 6.8$ & $73.9 \pm 6.0$ & $74.5 \pm 8.6$ & $52.1 \pm 6.5$ & $56.8 \pm 7.3$ \\
\hline $\mathrm{Ad}$ & $31.8 \pm 1.7$ & $34.6 \pm 1.3$ & $24.7 \pm 2.2$ & $25.4 \pm 0.8$ & $76.6 \pm 4.9$ & $77.1 \pm 2.0$ & $39.0 \pm 0.3$ & $39.7 \pm 0.4$ \\
\hline \multicolumn{9}{|l|}{ GluR4 } \\
\hline 3 & $20.7 \pm 1.7$ & $16.5 \pm 2.9$ & $19.5 \pm 1.2$ & $16.4 \pm 3.1$ & $24.1 \pm 5.1$ & $17.4 \pm 3.8$ & $51.0 \pm 5.9$ & $50.9 \pm 8.5$ \\
\hline 5 & $23.3 \pm 5.1$ & $18.5 \pm 4.6$ & $23.1 \pm 4.5$ & $20.2 \pm 4.0$ & $17.5 \pm 5.1$ & $11.5 \pm 3.1$ & $64.5 \pm 4.1$ & $68.5 \pm 3.5$ \\
\hline 7 & $24.5 \pm 2.1$ & $20.6 \pm 5.1$ & $23.1 \pm 5.0$ & $18.3 \pm 3.2$ & $19.1 \pm 5.7$ & $14.3 \pm 4.1$ & $78.8 \pm 4.3$ & $77.4 \pm 4.0$ \\
\hline 10 & $21.5 \pm 3.6$ & $21.4 \pm 2.4$ & $18.5 \pm 3.2$ & $16.5 \pm 3.3$ & $11.5 \pm 2.7$ & $15.6 \pm 5.7$ & $90.9 \pm 2.7$ & $83.0 \pm 3.0$ \\
\hline 14 & $23.8 \pm 3.1$ & $23.9 \pm 3.6$ & $15.7 \pm 2.2$ & $17.8 \pm 4.2$ & $18.5 \pm 1.8$ & $16.3 \pm 6.0$ & $96.0 \pm 1.4$ & $93.4 \pm 2.0$ \\
\hline 21 & $17.4 \pm 6.5$ & $19.4 \pm 4.0$ & $7.8 \pm 1.3$ & $8.5 \pm 1.1$ & $13.6 \pm 4.4$ & $16.9 \pm 2.7$ & $85.0 \pm 1.6$ & $88.0 \pm 2.4$ \\
\hline 33 & $14.7 \pm 3.5$ & $17.9 \pm 3.3$ & $8.4 \pm 2.4$ & $11.7 \pm 2.3$ & $17.9 \pm 3.3$ & $24.3 \pm 2.8$ & $88.9 \pm 2.7$ & $90.6 \pm 5.4$ \\
\hline $\mathrm{Ad}$ & $18.0 \pm 3.5$ & $15.6 \pm 3.4$ & $10.8 \pm 1.4$ & $9.6 \pm 2.9$ & $27.9 \pm 7.3$ & $19.3 \pm 3.0$ & $89.0 \pm 2.3$ & $88.2 \pm 1.9$ \\
\hline \multicolumn{9}{|l|}{ mGlu5 } \\
\hline 3 & $38.1 \pm 1.2$ & $40.2 \pm 2.1$ & $59.4 \pm 3.6$ & $61.9 \pm 4.5$ & $67.9 \pm 4.6$ & $71.2 \pm 5.4$ & nd & nd \\
\hline 5 & $45.3 \pm 1.7$ & $42.4 \pm 2.3$ & $72.1 \pm 4.0$ & $64.7 \pm 4.3$ & $82.8 \pm 2.9$ & $81.4 \pm 2.8$ & $12.4 \pm 3.7$ & $19.2 \pm 4.0$ \\
\hline 7 & $45.1 \pm 2.9$ & $40.5 \pm 2.2$ & $68.0 \pm 4.9$ & $58.9 \pm 3.3$ & $91.0 \pm 2.9$ & $86.0 \pm 2.0$ & $35.9 \pm 3.7$ & $36.1 \pm 3.8$ \\
\hline 10 & $37.8 \pm 2.7$ & $38.4 \pm 2.1$ & $55.2 \pm 3.8$ & $57.5 \pm 5.1$ & $88.5 \pm 6.8$ & $83.4 \pm 3.3$ & $34.9 \pm 9.3$ & $30.8 \pm 2.4$ \\
\hline 14 & $33.7 \pm 1.7$ & $35.6 \pm 2.6$ & $55.5 \pm 3.9$ & $55.3 \pm 4.4$ & $97.2 \pm 1.7$ & $92.0 \pm 2.3$ & $26.1 \pm 2.7$ & $30.4 \pm 3.5$ \\
\hline 21 & $26.6 \pm 3.2$ & $28.2 \pm 3.1$ & $43.4 \pm 3.2$ & $41.9 \pm 2.0$ & $75.9 \pm 5.0$ & $78.1 \pm 4.3$ & $4.8 \pm 3.8$ & $2.6 \pm 2.5$ \\
\hline 33 & $25.8 \pm 1.9$ & $24.5 \pm 2.0$ & $41.7 \pm 3.0$ & $36.5 \pm 2.5$ & $72.4 \pm 4.5$ & $75.4 \pm 4.7$ & $2.2 \pm 3.0$ & $4.3 \pm 0.2$ \\
\hline $\mathrm{Ad}$ & $26.5 \pm 2.0$ & $26.3 \pm 2.5$ & $47.5 \pm 2.5$ & $42.8 \pm 3.0$ & $84.2 \pm 4.6$ & $80.2 \pm 4.6$ & $5.2 \pm 5.2$ & $4.9 \pm 2.2$ \\
\hline
\end{tabular}

Semiquantitative analysis of autoradiographic signal obtained from in situ hybridization experiments showed no statistically significant difference in GluR1, GluR2, GluR3, GluR4, and mGlu5 mRNA expression between wt and Fmr 1 K0 mice at different postnatal days in each analyzed region (one-way ANOVA). Values were calculated as percentage of optical density levels in the region with the highest levels of expression for each receptor at P14 (hippocampus, GluR1, GluR2, GluR3, mGlu5; cerebellum, GluR4). Data represent mean \pm SEM of determinations from a total number of three to seven animals per time point. CTX, Cortex; STR, striatum; HIPP, hippocampus; CB, cerebellum; nd, not determined.

NMDA subunits, mGlu5 receptors, and Homer and Homerla isoforms. NR2A and Homer were not affected by Triton X-100 treatment, whereas Homerla was totally extracted; GluR1, GluR2/3, and GluR4 subunits and mGlu5 receptors showed an intermediate degree of solubility (Fig. 3C). Interestingly, Triton X-100 1\% extracted $\sim 15 \%$ more mGlu5 receptors in SPMs of Fmr1 KO than wt mice, whereas detergent solubility of the other tested proteins was not different between Fmr1 KO and control animals (Fig. 3A,B). Quantification of band intensity (Fig. 3C) and normalization of data with NR2A (Fig. 3D) and GluR1 (data not shown) confirmed a statistically significant reduction of mGlu5 receptors in the Triton X-100-insoluble fraction of Fmr1 KO mice. The same result as with $1 \%$ Triton $\mathrm{X}-100$ was obtained using a low concentration $(0.2 \%)$ of the ionic detergent Sarkosyl, which, at higher concentration (1\%), completely solubilized SPM proteins (data not shown). To ensure that the observed differences in mGlu5 detergent solubility did not result from different rates of protein degradation during extraction, we performed Western blotting experiments on total SPMs before extraction, total SPMs after extraction, and detergent-insoluble and -soluble fractions, and we were able to show that proteins were not destroyed by our experimental procedure. This experiment confirmed a different degree of solubility between NMDA and AMPA subunits and mGlu5 receptors by showing a different distribution of the tested proteins between insoluble and soluble fractions (Fig. 4).

\section{Reduced association between mGlu5 receptors and Homer proteins in SPMs of Fmr1 KO mice}

Considering the role of Homer proteins in anchoring mGluRs to PSD, we decided to compare the degree of association between mGlu5 receptors and Homer proteins by means of immunopre- 

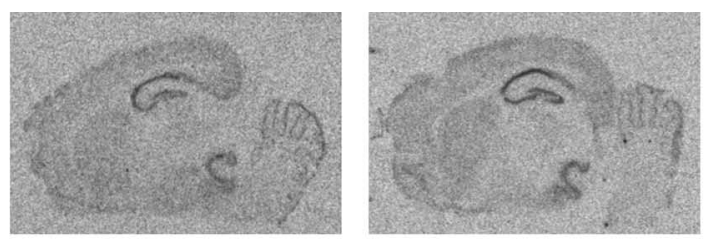

GluR1
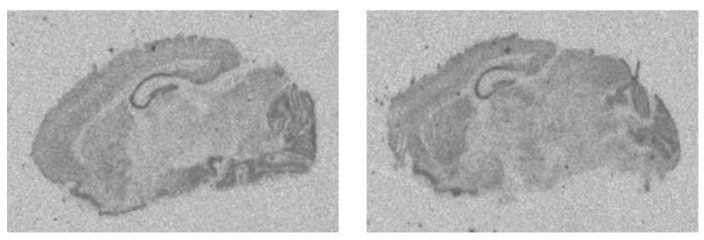

GluR2
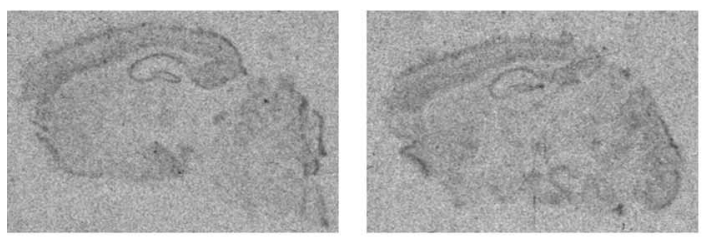

GluR3
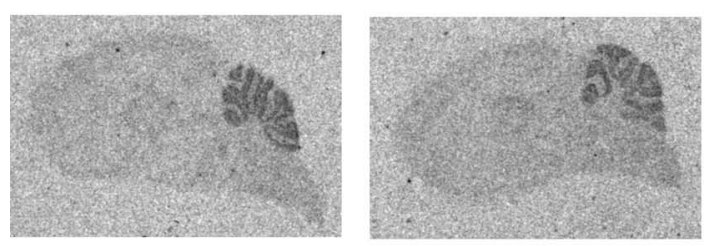

GluR4

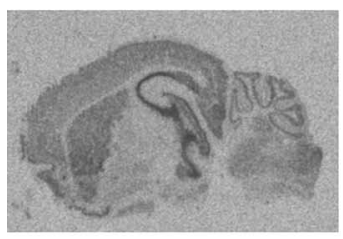

wt

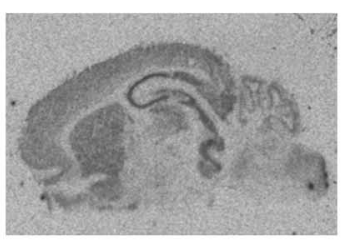

Fmr1 KO

Figure 1. Representative autoradiographic images of GluR1, GluR2, GluR3, GluR4, and mGlu5 receptor in situ hybridization in wt and $F m r 1 \mathrm{~K} 0$ mice at $\mathrm{P} 7$ show comparable expression patterns.

cipitation experiments. Interestingly, Western blotting experiments performed on anti-Homer-immunoprecipitated SPM proteins revealed a consistent and statistically significant reduction in the expression of mGlu5 receptors in Fmr1 KO compared with wt mice ( $-50 \% ; n=5 ; p<0.05$ by Student's $t$ test) (Fig. $5 A)$. This experiment confirmed that Homer expression is comparable between Fmr1 KO and wt mice, as observed previously in SPMs either treated or not with Triton X-100 (Fig. 3B). Specificity of the immunoprecipitation experiments was assessed by using kidney total extracts, which do not express Homer proteins (Soloviev et al., 2000).

Immunoprecipitation experiments with an anti-Homer 1a antibody were performed to investigate the possibility that those mGlu5 receptors that are not linked to Homer long forms might be more available for interaction with Homerla under control unstimulated condition. Although the efficiency of Homer 1a immunoprecipitation was low, a slight increase in the amount of mGlu5 levels was observed in two Fmr1 KO mice (Fig. 5B), whereas no change was detected in a third animal compared with wt animals (data not shown).

Homer is less tyrosine phosphorylated in Fmr1 KO compared with wt mice

Tyrosine phosphorylation of NR2A, GluR1, mGlu5, and Homer was assessed by Western blotting on phosphotyrosine-
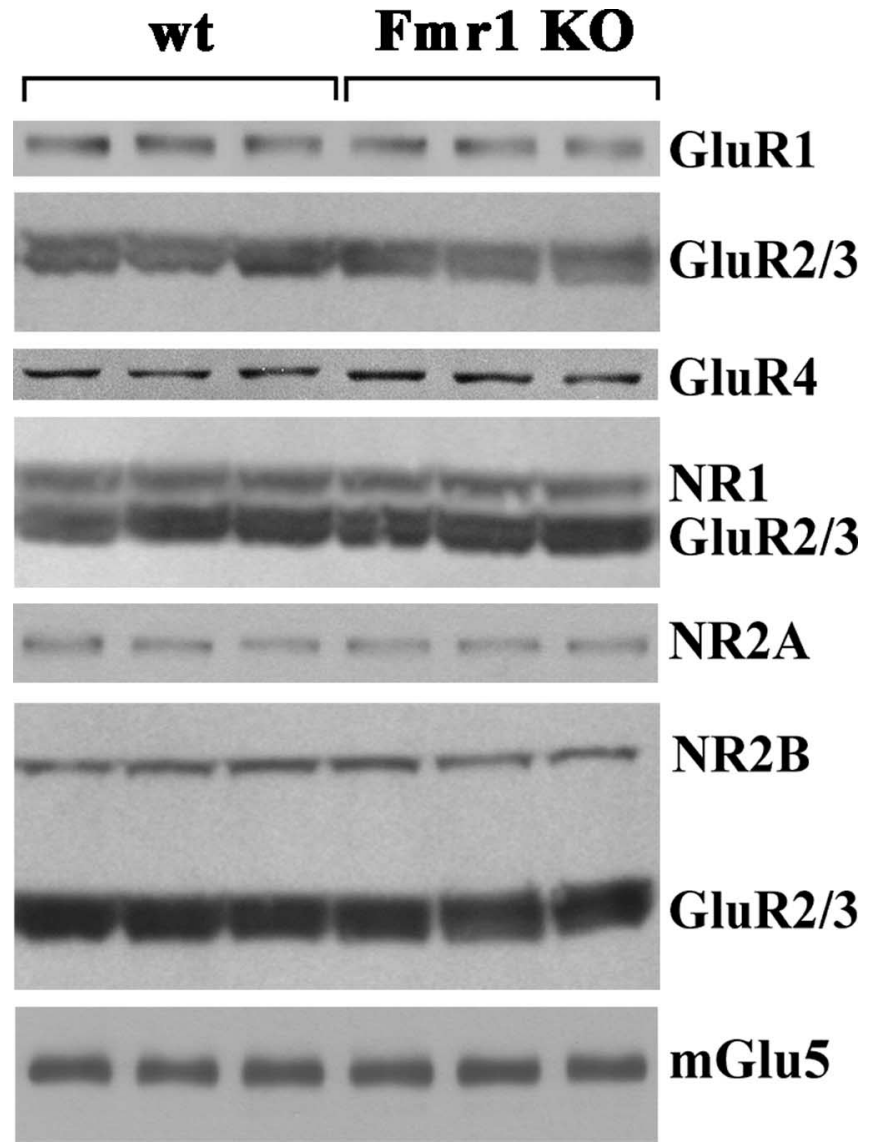

Figure 2. Expression of AMPA and NMDA subunits and mGlu5 receptors was comparable in TMPs from control and Fmr $1 \mathrm{KO}$ mice. Western blots of TMPs from control (wt) and Fmr $1 \mathrm{KO}$ mice at P14 are shown. Proteins were obtained from forebrain (GluR1, GluR2/3, NR1, NR2A, NR2B, and $\mathrm{mGlu5}$ ) and cerebellum (GluR4). Protein ( $40 \mu \mathrm{g}$ ) was loaded in each lane. Identical data were obtained at P5, P10, P14, P21, P30, and 11 months of age.

immunoprecipitated SPM proteins. The level of tyrosine phosphorylation was very high for NR2A, whereas GluR1 and mGlu5 receptors showed a much lower level of phosphorylation on tyrosine residues compared with the input lanes. These results are consistent with those reported previously (Orlando et al., 2002). Here, we show a strong tyrosine phosphorylation of Homer proteins, which was less intense in the Fmr1 KO compared with control mice. Semiquantitative analysis of optical density signal confirmed a statistically significant reduction in the tyrosine phosphorylation of Homer proteins in Fmr1 KO animals (Fig. 6).

\section{Discussion}

The main findings of the present paper can be summarized as follows: (1) AMPA subunits, NMDA subunits, mGlu5 receptors, and Homer proteins were similarly expressed in Fmr1 KO and wt animals in TMPs and SPMs; (2) Triton X-100 treatment revealed a selective reduction of mGlu5 expression in the detergentinsoluble fraction of SPMs in Fmr1 KO compared with control mice; (3) mGlu5 receptor levels were reduced in the Homerimmunoprecipitated fraction of SPMs from Fmr1 KO mice; and (4) tyrosine-phosphorylation of Homer proteins was reduced in SPMs from Fmr1 KO mice.

AMPA subunits, NMDA subunits, mGlu5 receptors, and Homer proteins were similarly expressed in Fmr1 KO and wt animals in TMPs and SPMs. In addition, the expression profile of AMPA subunit and mGlu5 receptor mRNAs was similar in Fmr1 
A

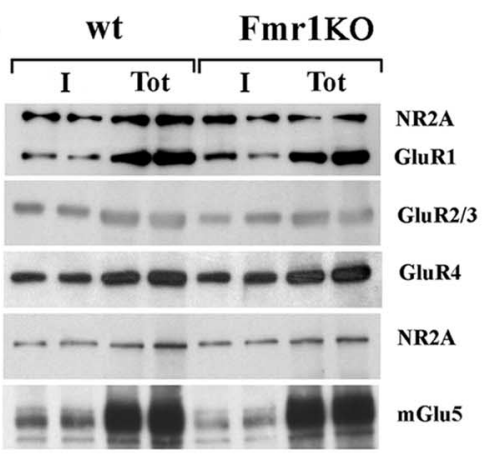

B

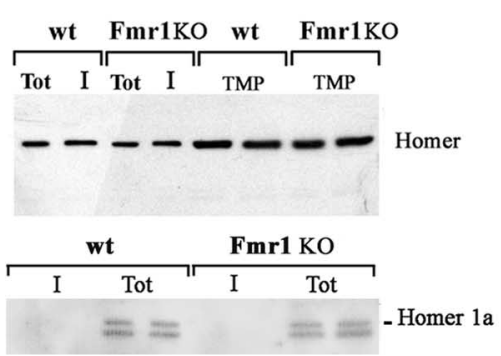

C

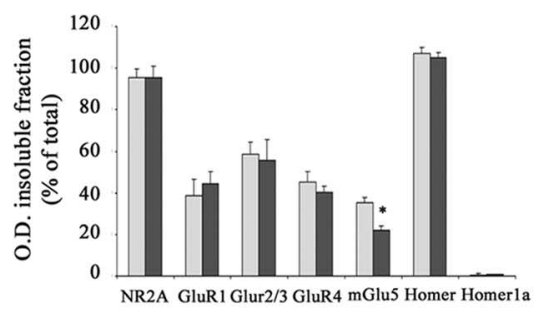

D

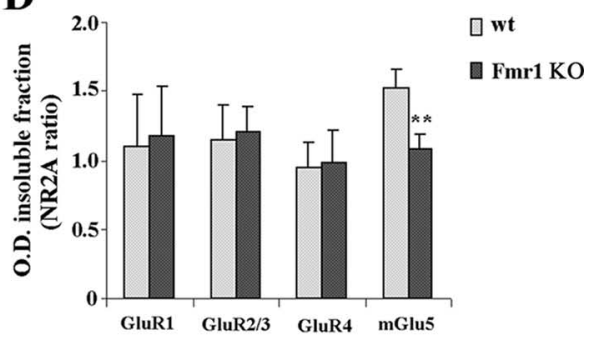

Figure 3. mGlu5 expression levels were lower in the Triton X-100-insoluble fraction of SPM proteins from Fmr $1 \mathrm{~K} 0$ than control mice. $\boldsymbol{A}, \boldsymbol{B}$, Western blots of SPM proteins from forebrains of P21 control (wt) and Fmr1 KO mice before (Tot) and after extraction with 1\% Triton X-100 (I) for NR2A, GluR1, GluR2/3, GluR4, mGlu5 ( $\boldsymbol{A})$, Homer ( $\boldsymbol{B}$, top, first 4 lanes), and Homer1a ( $\boldsymbol{B}$, bottom). Expression of Homer in TMPs under the identical experimental conditions is also shown ( $\boldsymbol{B}$, top, last 4 lanes). Protein (20 $\mu \mathrm{g})$ before and after Triton X-100 extraction was loaded on each lane except for GluR4 (30 $\mu \mathrm{g})$. Lanes loaded with untreated proteins (Tot) look overloaded because only a long exposure allowed the visualization of mGlu5 band in the insoluble fraction (I) of Fmr $1 \mathrm{KO}$ SPMs. The same films exposed for a shorter time did not show any difference in the amount of mGlu5 receptors in untreated SPMs. C, Relative optical density of bands in the insoluble fraction is presented as a percentage of the total fraction (wt, gray columns; Fmr $1 \mathrm{~K} 0$, black columns). Data are mean \pm SEM of $4-16$ experiments ( $n=16$ for NR2A; $n=9$ for GluR1; $n=4$ for GluR2/3; $n=$ 11 for GluR4; $n=14$ for mGlu5; $n=4$ for Homer and Homer1a; ${ }^{*} p<0.05$, Student's $t$ test). $\boldsymbol{D}$, Relative optical density of bands in the insoluble fraction is presented as a ratio of NR2A band in the same experiment ( ${ }^{* *} p<0.01$, Student's $t$ test).

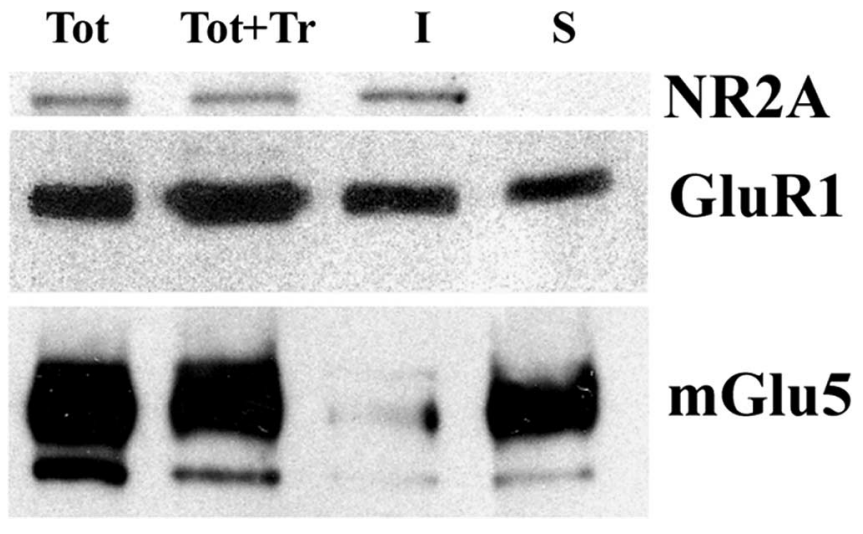

Figure 4. NR2A, GluR1, and mGlu5 are differentially distributed between detergent-soluble and -insoluble fraction of SPM proteins. Western blots of SPM proteins from Fmr $1 \mathrm{KO}$ forebrains at P21 before (Tot), after treatment with $1 \%$ Triton X-100 (Tot $+\mathrm{Tr}$ ), and after extraction and separation of insoluble $(\mathrm{I})$ and soluble $(\mathrm{S})$ fractions are shown. Protein $(20 \mu \mathrm{g})$ before and after extraction with Triton X-100 was loaded in each lane.

$\mathrm{KO}$ and wt animals during development. To our knowledge, only GluR1 and mGlu5 expression has been studied previously in Fmr1 KO animals (Li et al., 2001; Huber et al., 2002). Our data are partially consistent with the study of $\mathrm{Li}$ and coworkers reporting a reduction of GluR1 in cortical but not in hippocampal SPMs from Fmr1 KO mice. Considering that we obtained SPMs from the whole forebrain, it is possible that we missed some regional differences in GluR1 expression. However, the analysis of in situ

hybridization film autoradiographic signal did not reveal any regional difference in GluR1 mRNA expression, although we cannot exclude that subtle differences in glutamate receptor mRNA expression between Fmrl KO and control animals might be revealed by using more sensitive techniques. Our results are in line with data of Huber et al. (2002), who reported an increased mGlu-dependent hippocampal LTD in Fmrl KO mice but no difference in mGlu5 expression in total hippocampal homogenates from Fmrl KO and wt mice. Overall, our data indicate that, although Fmr1 $\mathrm{KO}$ animals have modification in synaptic plasticity, this is not likely attributable to an altered expression of the total and synaptic amount of receptors. These negative data do not exclude, however, the possibility that an altered organization of receptors and proteins at synapses might still underlie altered functional responses in these animals.

The degree of solubility to Triton $\mathrm{X}-100$ has been assumed to be an indicator of how tightly a protein is associated with PSD (Blahos and Wenthold, 1996; Allison et al., 1998; Park et al., 1999). AMPA subunits, NMDA subunits, mGlu5 receptors, Homer, and Homerla isoforms showed different levels of solubility to Triton $\mathrm{X}-100$, which was complete for Homerla, intermediate for GluR1, GluR2/3, GluR4 subunits and mGlu5 receptors, and very low for NR2A and Homer. The data regarding AMPA and NMDA subunits are consistent with previous reports (Blahos and Wenthold 1996; Wenthold et al., 1996; Allison et al., 1998; Park et al., 1999). Similarly to NR2A, Homer showed almost no solubility to Triton X-100, whereas Homerla was totally soluble. The differential extractability to Triton X-100 shown by the different Homer isoforms might be attributable to homomultimerization and interaction with other PSD molecules. Homer long forms self-associate and cluster with other PSD proteins (Tu et al., 1999), whereas Homer la does not (Brakeman et al., 1997; Xiao et al., 1998). Consequently, the Homer long forms, which are strongly associated with PSD structures, were not affected by Triton X-100 treatment, whereas Homerla was totally extracted. We found no difference in the expression of Homer and their solubility to Triton X-100 between Fmr1 KO and wt mice, indicating that the basal expression of Homer and their properties of multimerization and binding to PSD are not altered in these animals.

mGlu5 receptors as well as AMPA subunits were partially extractable with Triton X-100, indicating that two pools of mGlu5 receptors were present in SPMs: one tightly and another loosely anchored to PSD. The high detergent solubility of mGlu5 can be explained by its perisynaptic location (Luján et al., 1996) and the presence of highly diffusible mGlu5 receptors, which can move laterally away from the synapse (Sergé et al., 2002). The different detergent solubility properties of mGlu5 receptors in the Fmr1 $\mathrm{KO}$ mice might therefore suggest a different linkage with cytoskeleton scaffolding proteins, with a consequent different loca- 


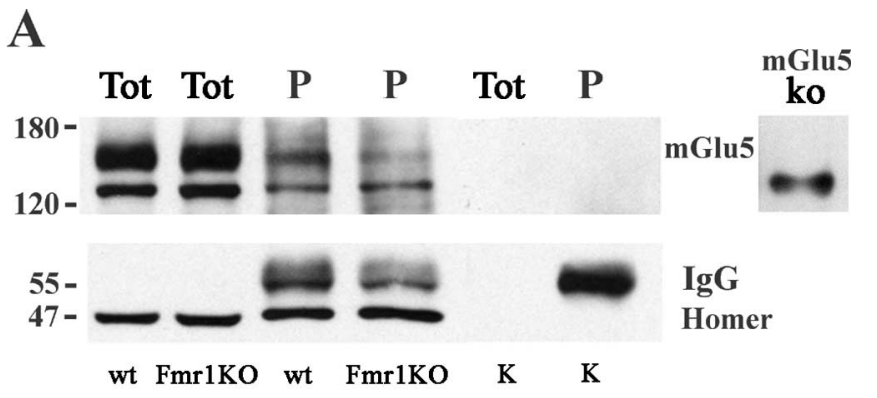

B

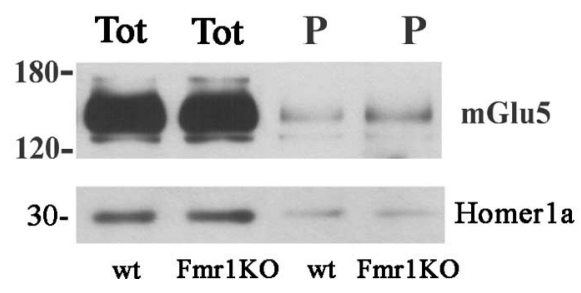

Figure 5. mGlu5 receptor expression was lower in the Homer-immunoprecipitated protein fraction of $F m r 1 \mathrm{KO}$ compared with control mice. Western blots of proteins immunoprecipitated with anti-Homer $(\boldsymbol{A})$ and anti-Homer1a $(\boldsymbol{B})$ antibodies from $30 \mu \mathrm{g}$ of forebrain SPMs of P21 control (wt) and Fmr $1 \mathrm{KO}$ mice are shown. Lanes were loaded with total SPM proteins (Tot) or with immunoprecipitated proteins (P). The last two lanes in $\boldsymbol{A}$ were loaded with cellular lysate from rat kidney (K), taken as negative control. Anti-mGlu5, anti-Homer, and anti-Homer1a antibodies were used for immunodetection.

tion at the synapse and/or a different lateral mobility of the receptors. We tested this hypothesis by performing mGlu5 Western blotting on Homer-immunoprecipitated proteins from SPMs. We found that, in Fmr1 KO mice, mGlu5 receptors are less associated with Homer long forms and therefore with the PSD, whereas a slight increase or no change in Homerlaimmunoprecipitated mGlu5 receptors was detected. The interaction between mGlu5 and Homer controls mGlu5 constitutive activity (Ango et al., 2001), mGlu5 cell surface expression and trafficking (Coutinho et al., 2001; Ango et al., 2002), mGlu5 lateral mobility (Sergé et al., 2002), and mGlu5 coupling to $\mathrm{IP}_{3}$ and ryanodine receptors of the endoplasmic reticulum (Tu et al., 1998) and to ion channels of the cytoplasmic membrane (Kammermeier et al., 2000), with important consequences for mGlu5 receptor-dependent transduction signals. The presence of an increased amount of mGlu5 receptors not linked to Homer proteins in Fmr1 KO animals might mimic a synaptic activity situation in which the induction of Homerla disrupts the interactions of mGluRs with Homer long forms. In fact, Homerla is the only form rapidly induced by synaptic activity (Brakeman et al., 1997), whereas long isoforms are constitutively expressed (Tu et al., 1998) and, when induced, disrupts the clusters formed by constitutive Homer and competes with the long forms to bind ligands, behaving as a dominant negative (Xiao et al., 1998). Although the basal levels of Homerla were not changed, Homerla immunoprecipitation experiments support the possibility of a shift in mGlu5 binding from Homer to Homerla in Fmr1 $\mathrm{KO}$ animals. However, considering that under unstimulated control condition the amount of Homerla is low compared with long Homer isoforms, a more sensitive technique might better demonstrate that mGlu5 receptors are indeed more associated with Homerla in Fmr1 $\mathrm{KO}$ animals.

Thus, in Fmrl KO animals, we might expect an increased mGlu5 constitutive activity, cell surface expression, and lateral mobility as well as a more efficient coupling to N-type calcium
A
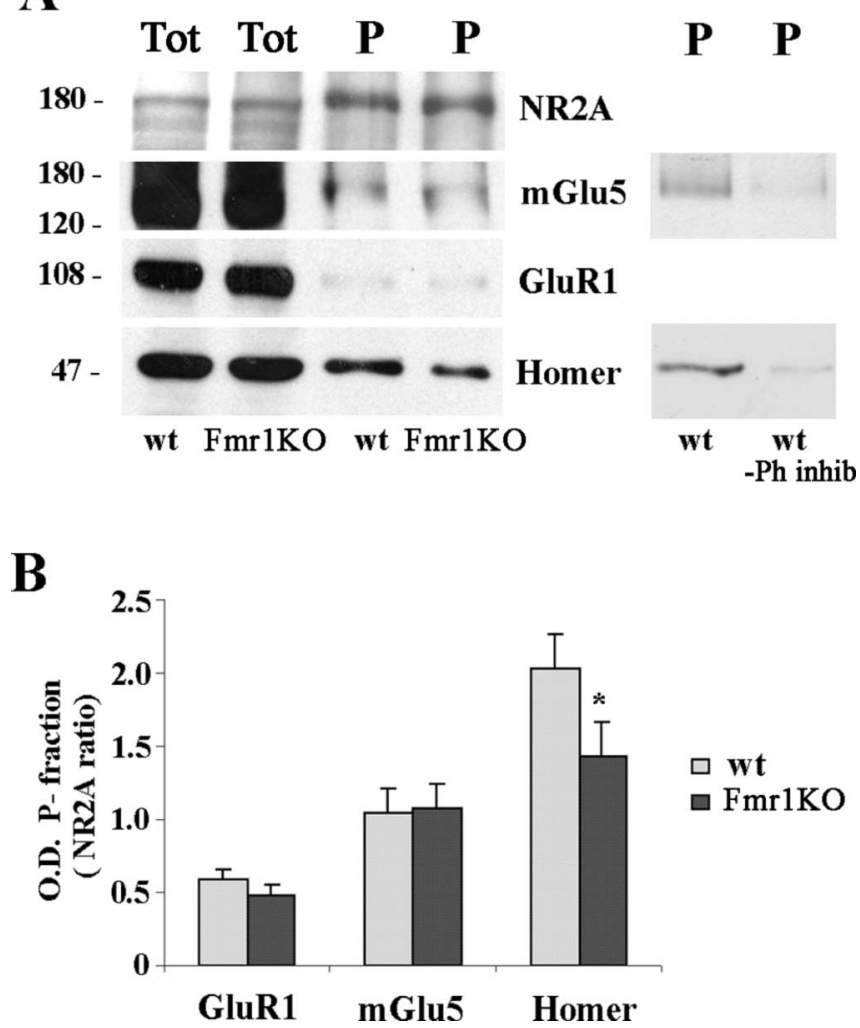

Figure 6. Homer was less tyrosine phosphorylated in Fmr $1 \mathrm{KO}$ than control mice, whereas NR2A, mGlu5, and GluR1 were equally phosphorylated in both wt and $F m r 1 \mathrm{~K} 0$ mice. $A$, Western blots of proteins immunoprecipitated with anti-phosphotyrosine antibody from $30 \mu \mathrm{g}$ of forebrain SPMs of P21 control (wt) and Fmr1 K0 mice. Lanes were loaded with total SPM proteins (Tot) or with immunoprecipitated proteins (P). Anti-NR2A, anti-mGlu5, anti-GluR1, and antiHomer antibodies were used for immunodetection. A control experiment performed in the absence of phosphatase inhibitor (Ph inhib) shows a strong reduction in tyrosine phosphorylation levels of Homer and mGlu5 proteins. B, Quantification of GluR1, mGlu5, and Homer compared with NR2A levels in the immunoprecipitated fraction of wt (gray columns) and Fmr $1 \mathrm{KO}$ (black columns) mice. Data are mean of four to nine experiments ( $n=4$ for GluR1; $n=8$ for mGlu5; $n=9$ for Homer; ${ }^{*} p<0.05$, Student's $t$ test).

and M-type potassium channels (Kammermeier et al., 2000). None of these possibilities has been directly tested in Fmr1 KO animals. We speculate that our finding of an increased amount of freely diffusible mGlu5 receptors is plausible within a recently proposed scenario of an overall increased activity of mGlu5 receptors in FRAX syndrome (Bear et al., 2004). In fact, the overstimulation of the mGlu5 receptors might lead to an increased turnover and/or to an increased lateral mobility of mGlu5 receptors, because it has been demonstrated after stimulation with the agonist (RS)-3,5-dihydroxyphenylglycine (DHPG) (Sergé et al., 2002). Furthermore, considering that the coactivation of mGlu and NMDA receptors is necessary for the induction of LTP (Bashir et al., 1993; Fujii et al., 2003), the disruption of the coupling between mGlu5 and NMDA receptors mediated by Homer proteins might also explain the LTP reduction observed in the cortex of Fmrl KO mice after tetanic stimulation (Li et al., 2001). An increased susceptibility to epileptic seizures is a feature of FRAX patients (Musumeci et al., 1988, 1999), as well as Fmr1 KO animals (Musumeci et al., 2000). It is intriguing that disruption of group I mGlu-Homer complex is associated with a more efficient inhibition of potassium currents (Kammermeier et al., 2000), with a consequent alteration of neuronal excitability (Marrion, 1997). Interestingly, the mGlu5 antagonist 2-methyl- 
6-(phenylethynyl)-pyridine suppresses audiogenic seizure susceptibility in FRAX mice (Yan et al., 2005) and reverses some features of the Drosophila model of FRAX syndrome (McBride et al., 2005).

Tyrosine dephosphorylation is a crucial event in LTD induction after stimulation of group I mGlu receptors with the selective agonist DHPG, although the molecular target of tyrosine dephosphorylation has not been yet identified (Moult et al., 2002). Here, we show that Homer long isoforms are strongly phosphorylated on tyrosine residues and that Homer proteins from SPMs of Fmr 1 $\mathrm{KO}$ mice are less tyrosine phosphorylated compared with control animals. Protein tyrosine kinases of the Src family and protein phosphatases are major constituents of PSD (Kennedy et al., 1983; Dosemeci and Reese, 1993; Suzuki and Okumura, 1995). These enzymes regulate the phosphorylation and dephosphorylation of postsynaptic proteins that are crucial events for both trafficking and turnover of receptors and other PSD proteins to the synapse, and, consequently, for the organization of PSD and synaptic plasticity (Colledge et al., 2003). We found a tyrosine consensus sequence in the Homer2 isoform of the Homer family by using the Expasy prosite database. The function of Homerphosphorylation status is presently unknown. A recent paper reported that glutamate induces posttranslation modifications of Homer2 isoforms, which are phosphatase activity dependent (Shiraishi et al., 2003). Our data demonstrate directly that Homer proteins are phosphorylated on tyrosine residues. It will be very interesting to reveal the mechanisms that lead to a reduced tyrosine phosphorylation of Homer proteins in Fmr1 KO animals and to verify the hypothesis that, in Fmrl KO mice, the enhancement of mGluR-dependent LTD might be related to a reduced tyrosine phosphorylation on Homer proteins. Whether Homer tyrosine phosphorylation regulates the association with mGlu5 will be matter of future investigations.

\section{References}

Allison DW, Gelfand VI, Spector I, Craig AM (1998) Role of actin in anchoring postsynaptic receptors in cultured hippocampal neurons: differential attachment of NMDA versus AMPA receptors. J Neurosci 18:2423-2436.

Ango F, Prézeau L, Muller T, Tu JC, Xiao B, Worley PF, Pin JP, Bockaert J, Fagni L (2001) Agonist-independent activation of metabotropic glutamate receptors by the intracellular protein Homer. Nature 411:962-965.

Ango F, Robbe D, Muller T, Tu JC, Xiao B, Worley PF, Pin JP, Bockaert J, Fagni L (2002) Homer-dependent cell surface expression of metabotropic glutamate receptor type 5 in neurons. Mol Cell Neurosci 20:323-329.

Antar LN, Afroz R, Dictenberg JB, Carrol RC, Bassel GJ (2004) Metabotropic glutamate receptor activation regulates fragile $\mathrm{X}$ mental retardation protein and Fmrl mRNA localization differentially in dendrites and at synapses. J Neurosci 24:2648-2655.

Aschrafi A, Cunningham BA, Edelman GM, Vanderklish PW (2005) The fragile X mental retardation protein and group I metabotropic glutamate receptors regulate levels of mRNA granules in brain. Proc Natl Acad Sci USA 102:2180-2185.

Bashir ZI, Bortolotto ZA, Davies CH, Berretta N, Irving AJ, Seal AJ, Henley JM, Jane DE, Watkins JC, Collingridge GL (1993) Induction of LTP in the hippocampus needs synaptic activation of glutamate metabotropic receptors. Nature 363:347-350.

Bear MF, Huber KM, Warren ST (2004) The mGluR theory of fragile X mental retardation. Trends Neurosci 27:370-377.

Blahos IIJ, Wenthold RJ (1996) Relationship between N-methyl-Daspartate receptor NR1 splice variants and NR2 subunits. J Biol Chem 271:15669-15674.

Brakeman PR, Lanahan AA, O’Brien R, Roche K, Barnes CA, Huganir RL, Worley PF (1997) Homer: a protein that selectively binds metabotropic glutamate receptors. Nature 386:284-288.

Brown V, Jin P, Ceman S, Darnell JC, O'Donnel WT, Tenenbaum SA, Jin X, Feng Y, Wilkinson KD, Keene JK, Darnell RB, Warren ST (2001) Mi- croarray identification of FMRP-associated brain mRNAs and altered mRNA translational profiles in Fragile X syndrome. Cell 107:477-487.

Carrol RC, Beattie EC, von Zastrow M, Malenka RC (2001) Role of AMPA receptor endocytosis in synaptic plasticity. Nat Rev Neurosci 2:315-324.

Catania MV, Landwehrmeyer GB, Testa CM, Standaert DG, Penney Jr JB, Young AB (1994) Metabotropic glutamate receptors are differentially regulated during development. Neuroscience 61:481-495.

Colledge M, Snyder EM, Crozier RA, Soderling JA, Jin Y, Langeberg LK, Lu H, Bear MF, Scott JD (2003) Ubiquitination regulates PSD-95 degradation and AMPA receptor surface expression. Neuron 40:595-607.

Comery TA, Harris JB, Willems PJ, Oostra BA, Irvin SA, Weiler IJ, Greenough W (1997) Abnormal dendritic spines in fragile X knockout mice: maturation and pruning deficits. Proc. Natl Acad Sci USA 94:5401-5404.

Coutinho V, Kavanagh I, Sugiyama H, Tones MA, Henley JM (2001) Characterization of a metabotropic glutamate receptor type 5-green fluorescent protein chimera (mGluR5-GFP): pharmacology, surface expression, and differential effects of Homer-1a and Homer-1c. Mol Cell Neurosci 18:296-306.

Darnell JC, Jensen KB, Jin P, Brown V, Warren ST, Darnell RB (2001) Fragile $\mathrm{X}$ mental retardation protein targets $\mathrm{G}$ quartet mRNAs important for neuronal function. Cell 107:489-499.

Dosemeci A, Reese TS (1993) Inhibition of endogenous phosphatase in a postsynaptic density fraction allows extensive phosphorylation of the major postsynaptic density protein. J Neurochem 61:550-555.

Dutch-Belgian Fragile X Consortium (1994) Fmr1 knockout mice: a model to study fragile X mental retardation. Cell 78:23-33.

Fujii S, Mikoshiba K, Kuroda Y, Ahmed TM, Kato H (2003) Cooperativity between activation of metabotropic glutamate receptors and NMDA receptors in the induction of LTP in hippocampal CA1 neurons. Neurosci Res 46:509-521.

Harlow E, Lane B (1988) Immunoaffinity purification. In: Antibodies laboratory manual. Cold Spring Harbor, NY: Cold Spring Harbor Laboratory.

Hinton VJ, Brown WT, Wisniewski K, Rudelli RD (1991) Analysis of neocortex in three males with the fragile X syndrome. Am J Med Genet 41:289-294.

Huber KM, Gallaher SM, Warren ST, Bear MF (2002) Altered synaptic plasticity in a mouse model of fragile X mental retardation. Proc Natl Acad Sci USA 99:7746-7750.

Jin P, Warren SR (2003) New insights into fragile X syndrome: from molecules to neurobehaviors. Trends Biochem Sci 28:152-157.

Kammermeier PJ, Xiao B, Tu JC, Worley PF, Ikeda SR (2000) Homer proteins regulate coupling of group I metabotropic glutamate receptors to N-type calcium and M-type potassium channel. J Neurosci 20:7238-7245.

Kennedy MB, Bennett MK, Erondu NE (1983) Biochemical and immunochemical evidence that the "major postsynaptic density protein" is a subunit of a calmodulin-dependent protein kinase. Proc Natl Acad Sci USA 80:7357-7361.

Laggerbauer B, Ostareck D, Keidel EM, Ostareck-Lederer A, Fischer U (2001) Evidence that fragile X mental retardation protein is a negative regulator of translation. Hum Mol Genet 10:329-338.

Li J, Pelletier MR, Perez Velasquez J-L, Carlen PL (2002) Reduced cortical synaptic plasticity and Glur1 expression associated with fragile X mental retardation protein deficiency. Mol Cell Neurosci 19:138-151.

Li Z, Zhang Y, Ku L, Wilkinson KD, Warren ST, Feng Y (2001) Evidence that fragile $\mathrm{X}$ mental retardation protein inhibits translation via interacting with mRNA. Nucleic Acids Res 29:2276-2283.

Luján R, Nusser Z, Roberts JD, Shigemoto R, Somogyi P (1996) Perisynaptic location of metabotropic glutamate receptors mGluR1 and mGluR5 on dendrites and dendritic spines in the rat hippocampus. Eur J Neurosci 8:1488-1500.

Marrion NV (1997) Control of M-current. Annu Rev Physiol 59:483-504.

McBride SM, Choi CH, Wang Y, Liebelt D, Braunstein E, Ferreiro D, Sehgal A, Siwicki KK, Dockendorff TC, Nguyen HT, McDonald TC, Jongens TA (2005) Pharmacological rescue of synaptic plasticity, courtship behavior, and mushroom body defects in a Drosophila model of Fragile X syndrome. Neuron 45:753-764.

Monyer H, Seeburg PH, Wisden W (1991) Glutamate operated channels: developmentally early and mature forms arise by alternative splicing. Neuron 6:799-810.

Moult PR, Schnabel R, Kilpatrick IC, Bashir ZI, Collingridge GL (2002) Tyrosine dephosphotylation underlies DHPG-induced LTD. Neuropharmacology 43:175-180. 
Musumeci SA, Colognola RM, Ferri R, Gigli GL, Petrella MA, Sanfilippo S, Bergonzi P, Tassinari CA (1988) Fragile-X syndrome: a particular epileptogenic EEG pattern. Epilepsia 29:41-47.

Musumeci SA, Hagerman RJ, Ferri R, Bosco P, Bernardina BD, Tassinari CA, De Sarro GB, Elia M (1999) Epilepsy and EEG findings in males with fragile X syndrome. Epilepsia 40:1092-1099.

Musumeci SA, Bosco P, Calabrese G, Bakker C, De Sarro GB, Elia M, Ferri R, Oostra BA (2000) Audiogenic seizures susceptibility in transgenic mice with fragile X syndrome. Epilepsia 41:19-23.

Nimchinsky EA, Oberlander AM, Svoboda K (2001) Abnormal development of dendritic spines in FMR1 knock-out mice. J Neurosci 21:5139-5146.

Orlando LR, Dunah AW, Standaert DG, Young AB (2002) Tyrosine phosphorylation of the metabotropic glutamate receptor mGluR5 instriatal neuron. Neuropharmacology 43:161-173.

Park HT, Jeon ES, Bae KW (1999) Postnatal development of detergentinsoluble properties of NMDA and AMPA receptor subunits in the rat brain synaptic membrane. Dev Brain Res 115:83-87.

Sakimura K, Bujo H, Kushiya E, Araki K, Yamazaki M, Yamazaki M, Meguro H, Warashina A, Numa S, Mishina M (1990) Functional expression from cloned cDNAs of glutamate receptor species responsive to kainate and quisqualate. FEBS Lett 272:73-80.

Scannevin RH, Huganir RL (2000) Postsynaptic organization and regulation of excitatory synapses. Nat Rev Neurosci 1:133-141.

Sergé A, Fourgeaud L, Hémar A, Choquet D (2002) Receptor activation and Homer differentially control the lateral mobility of metabotropic glutamate receptor 5 in the neuronal membrane. J Neurosci 22:3910-3920.

Shiraishi Y, Mizutani A, Yuasa S, Mikoshiba K, Furuichi T (2003) Glutamate-induced declustering of post-synaptic adaptor protein Cupidin (Homer 2/vesl-2) in cultured cerebellar granule cells. J Neurochem 87:364-376.

Soloviev MM, Ciruela F, Chan W, McIlhinney JRA (2000) Mouse brain and muscle tissues constitutively express high levels of Homer proteins. Eur J Neurochem 267:634-639.

Sommer B, Kohler M, Sprengel R, Seeburg PH (1991) RNA editing in brain controls a determinant of ion flow in glutamate-gated channels. Cell 67:11-19.

Sung YJ, Dolzhanskaya N, Nolin SL, Brown T, Currie JR, Denman RB (2003)
The Fragile X mental retardation Protein FMRP binds elongation factor $1 \mathrm{~A}$ mRNA and negatively regulates its translation in vivo. J Biol Chem 278:15669-15678.

Suzuki T, Okumura NK (1995) NMDA receptor subunits epsilon 1 (NR2A) and epsilon 2 (NR2B) are substrates for Fyn in the postsynaptic density fraction isolated from rat brain. Biochem Biophys Res Commun 216:582-588.

Tu JC, Xiao B, Yuan JP, Lanahan AA, Leoffert K, Li M, Linden DJ, Worley PF (1998) Homer binds a novel prolin-rich motif and links group 1 metabotropic glutamate receptors with IP3 receptors. Neuron 21:717-726.

Tu JC, Xiao B, Naisbitt S, Yuan JP, Petralia RS, Brakeman P, Doan A, Aakalu VK, Lanahan AA, Sheng M, Worley PF (1999) Coupling of mGluR/ Homer and PSD-95 complexes by the Shank family of postsynaptic density protein. Neuron 23:583-592.

Weiler IJ, Irwin SA, Klintsova AY, Spencer CM, Brazelton AD, Miyashiro K, Comery TA, Patel B, Eberwine J, Greenough WT (1997) Fragile X mental retardation protein is translated near synapses in response to neurotransmitter activation. Proc Natl Acad Sci USA 94:5395-5400.

Weiler IJ, Spangler CC, Klintsova AY, Grossman AW, Kim SH, BertainaAnglade V, Khaliq H, de Vries E, Lambers FAE, Hatia F, Base CK, Greenough WT (2004) Fragile X mental retardation protein is necessary for neurotransmitter-activated protein translation at synapses. Proc Natl Acad Sci USA 101:17504-17509.

Wenthold RJ, Petralia RS, Blahos IIJ, Niedzielski AS (1996) Evidence for multiple AMPA receptor complexes in hippocampal CA1/CA2 neurons. J Neurosci 16:1982-1989.

Xiao B, Tu JC, Petralia RS, Yuan JP, Doan A, Breder CD, Ruggiero A, Lanahan AA, Wenthold RJ, Worley PF (1998) Homer regulates the association of group 1 metabotropic glutamate receptors with multivalent complexes of Homer-related, synaptic proteins. Neuron 21:707-716.

Yan QJ, Rammal M, Tranfaglia M, Bauchwitz RP (2005) Suppression of two major Fragile X syndrome mouse model phenotypes by the mGluR5 antagonist MPEP. Neuropharmacology, in press.

Zalfa F, Giorgi M, Primerano B, Moro A, Di Penta A, Reys S, Oostra B, Bagni C (2003) The fragile X syndrome protein FMRP associates with BCl RNA and regulates the translation of specific mRNA at synapses. Cell 112:317-327. 